\title{
Market reaction to bank merger and acquisition events in Brazil: an analysis of the effects of market waves ${ }^{\star}$
}

\author{
João Gabriel de Moraes Souza ${ }^{1,2}$ \\ (D) https://orcid.org/0000-0003-0685-3082 \\ Email: joaogabrielsouza@yahoo.com.br \\ Ivan Ricardo Gartner ${ }^{1}$ \\ (D) https://orcid.org/0000-0002-9780-1212 \\ Email: irgartner@unb.br
}

\author{
1 Universidade de Brasília, Faculdade de Economia, Administração, Contabilidade e Gestão de Políticas Públicas, Programa de Pós-Graduação \\ em Administração, Brasília, DF, Brazil \\ ${ }^{2}$ Instituto de Pesquisa Econômica Aplicada, Brasília, DF, Brazil
}

Received on 08.07.2017 - Desk acceptance on 09.06.2017 - $5^{\text {th }}$ version approved on 08.04.2018 - Ahead of print on 02.18.2019

Associate Editor: Fernanda Finotti Cordeiro Perobelli

\begin{abstract}
The aim of this study is to investigate the stock market's reaction to bank merger and acquisition (M\&A) events in Brazil when the market is heated. This article aims to fill the research gap involving bank M\&As and their effects, especially those arising from M\&A waves. This field remains open in the literature; there is no consensus as to the abnormal returns the investor can expect from this mechanism. The notion that bank M\&A markets heat up is discussed and still does not present a consensus in the literature. Therefore, topics that involve research on specific M\&A strategies and their effects are interesting for the literature. The results of this research point to the emergence of positive cumulative abnormal returns for rivals of newly-merged acquiring banks and zero ones for acquired banks. This analysis occurs because in heated markets the probability of rival banks becoming involved in M\&As increases, leading to market gains and greater market power for acquiring banks and the rapid pricing of acquired bank assets. This result corroborates with the post-merger analysis, in which the accounting performance indicators of the acquiring banks are positive. The market reaction was verified through the use of the event study econometric technique, which was applied in the investigation of the occurrence of abnormal returns in time windows of up to 41 days around the bank M\&A events. The study measured the stock market's reaction to a motivation for M\&As, which is the effect of M\&A waves. This article contributes to the literature by highlighting specific forms of bank M\&As. In particular, the logic of merger by market forces is addressed. This mechanism of mergers by market forces is presented as evidence of the tendency for M\&As and not of paid-in earnings.
\end{abstract}

Keywords: mergers and acquisitions, banks, market waves, event studies, quantile regression.

Correspondence address

João Gabriel de Moraes Souza

Universidade de Brasília, Faculdade de Economia, Administração, Contabilidade e Gestão de Políticas Públicas, Programa de Pós-Graduação em Administração

Campus Universitário Darcy Ribeiro, Bloco A-2 - CEP: 70910-900

Asa Norte - Brasília - DF - Brazil

*Paper presented at the XXXIX National ANPAD Conference, September 2015, Belo Horizonte, MG, Brazil. 


\section{INTRODUCTION}

There is extensive literature on the value gains (positive abnormal returns) of rivals of recently-merged firms (Song \& Walkling, 2000). These studies begin with Eckbo (1983, $1985)$ and extend to the research by Song and Walkling (2000) and Hankir, Rauch, and Umber (2011); however, in this field, the Brazilian literature is scarce. These studies have, for the most part, found positive abnormal returns in rivals of newly-merged firms. The most widely-used explanation in the literature is that horizontal mergers eliminate competitors and enable collusions between the remaining firms in the market.

Yet, the article by Eckbo and Wier (1985) rejects this hypothesis that, by eliminating competitors, horizontal mergers facilitate the collusion of the remaining companies, leaving open the explanation for the positive returns of the rivals of recently-merged firms (Eckbo, 1983, 1985; Eckbo \& Wier, 1985; Hankir et al., 2011; Song \& Walkling, 2000).

Song and Walkling (2000) trace a parallel between the probability of a bank being merged and the abnormal returns observed in the market in relation to the concentration resulting from mergers and acquisitions (M\&As). According to Hankir et al. (2011), the positive abnormal return found in the rival banks of those recentlyconglomerated by the market can be observed by the fact the market is heated and, with this, the investors of rival firms expect their companies to be closer to being merged.

This article aims to contribute to this point and, therefore, seeks to answer the following question: what is the market's reaction in terms of the share prices of rival banks of recently-merged ones in heated markets? With this, the article investigates the occurrence of market reactions to M\&A events via an analysis of supposed abnormalities in the share returns of rivals of recentlymerged banks, as well as possible causal relationships derived from this, the latter being analyzed by means of quantile and interquantile regressions, covering the period from 2005 to 2015.

The studies that analyze the effects of M\&A waves limit themselves to observing the signs of the abnormal returns of the rivals of recently-merged firms to then determine asymmetric effects of M\&A waves on the market. Yet, why these abnormal returns of the rivals to recently-merged firms occur as a result of M\&A processes is not widely addressed in the literature. In this study, we attempt to contemplate this exact research gap.

Another point that this paper aims to address is to offer inputs for investors and market analysts regarding the possible causes of M\&As, such as M\&A waves and heated markets, as well as contributing with elements for regulatory entities and monetary authorities to take decisions about market regulations.

The main results found in this study are positive cumulative abnormal returns of the rivals of recentlymerged banks. These conclusions are consistent with the ideas of Song and Walkling (2000) and Hankir et al. (2011), that such returns are explained by heated M\&A markets, which probably facilitates the incorporations of the rivals of recently-merged banks. By analyzing the accounting indicators explaining cumulative abnormal returns, it is observed that the concentration indicators generally present negative effects, showing the dissatisfaction of the investors of rival banks of recently-merged ones with the market concentration. Positive effects on the financial performance indicators of merged banks are also observed in relation to the cumulative abnormal return of rival banks, and it is expected that, by merging, the bank presents operational gains, indicating a heated market. The values of the M\&A operations also show positive effects in relation to the cumulative abnormal returns of rival banks, indicating that the market is heated. For the analysis of pending M\&As, in which only announcements occurred, with no actual M\&As, investors priced the pending $M \& A s$ of the rival banks negatively, which shows that, in this case, the probability of their banks carrying out mergers is lower. With this, it is observed that investors believe that the bank M\&As market is one that is governed by the M\&A waves mechanism, that is, via heated markets.

This study is structured in the following way: section 2 presents the literature on the stock market's reaction to bank M\&A events in heated markets and the theoretical methodology. Section 3 addresses the analysis methodology, involving the data source and sample definition, a description and definition of the variables used, and the empirical methodology. Section 4 presents the study's empirical analysis and section 5 concludes the article with the final remarks. 


\section{STOCK MARKET REACTION TO BANK M\&A EVENTS IN HEATED MARKETS}

The banking sector forms part of the companies that have undergone strategic turbulences in the last three decades. In response to regulatory and technological alterations, as well as the globalization movement, the organizational structure of companies in the banking sector have been undergoing constant changes (Asimakopoulos \& Athanasoglou, 2013; Pessanha, Calegario, Sáfadi, \& Ázara, 2012). These alterations reinforce M\&A movements and, consequently, the stock market's reaction in relation to these events.

To introduce the subject, we choose the paper by Hankir et al. (2011), in which the authors narrate that the studies in relation to M\&A events began at the end of the 1970s and beginning of the 1980s. The seminal papers that use the event study method in finance to measure the abnormal returns derived from M\&A events are: Dodd and Ruback (1977), Dodd (1980), and Asquith (1983). These studies analyzed the abnormal returns in acquiring and acquired companies related to M\&A announcements and implementations.

Also in line with Hankir et al. (2011), positive abnormal returns for acquired firms occur via the synergistic process arising from M\&A events. For Arık and Kutan (2015), besides the intrinsic gains derived from the synergistic effects, as shown by Hankir et al. (2011), target firms generate values by merging. This fact especially occurred right after the last financial crisis of 2007/2008. According to Beltratti and Paladino (2013), positive abnormal returns occurred during the 2007-2010 financial crisis period due to the positive perception of investors resulting from the M\&As in that period. This reaction may occur because big stable banks are expected to absorb small and unstable ones, thus regulating the market. However, the negative abnormal returns found in the acquiring firms may derive from the lack of credibility of the synergistic effects in these banks, from the observance of a more concentrated market (market power), and from the acquisition of banks with financial problems (financial distress).

Another paper with this perspective is that of Hagendorff, Collins, and Keasey (2008), in which the authors state that in an efficient market asset prices are formed by rational agents, and changes in asset values (caused by M\&A events) serve as precise evaluations of the net benefits or harm to shareholders. This information is essential for investor analyses. According to the authors, the literature on the stock market's reaction to M\&A events reports that the investors of acquiring firms are skeptical about the gains associated with M\&A events.

Campa and Hernando (2006) state that the abnormal returns of acquiring banks originating from M\&A events are negative and mildly significant, with the same results being found by Brito, Batistella, and Famá (2005), Delong and DeYoung (2007), Hagendorff et al. (2008), Hankir et al. (2011), Andriosopoulos and Yang (2015), and Varmaz and Laibner (2016). According to Delong and DeYoung (2007), the academic studies have difficulties in finding value creation processes arising from M\&A events in commercial banks. These results may be explained by hubris management problems (when managers expose themselves to excessive risks) and others related to the principal-agent mechanism (Delong \& DeYoung, 2007).

In the Brazilian context, the literature has presented various incentives for the implementation of bank M\&As, such as the expansion of global financial conglomerates, government incentives to stabilize the economy in the mid 1990s, the privatization of public banks etc. (Pessanha et al., 2012). The paper by Brito et al. (2005) finds essentially negative returns on M\&As of acquiring banks directly involved in mergers. The same economic result can be seen in Araújo, Goldner, Brandão, and Oliveira (2007), in which the authors did not find profitability gains for acquiring banks directly involved in M\&As. However, that paper used a different panel data methodology from the event study methodology employed in this one and in the others cited. Nonetheless, using time series analysis, Pessanha et al. (2012) found positive impacts on the profitability indicators of banks directly involved in M\&As, but these impacts are low in intensity. These results show that the studies in this area still lack an in-depth analysis of the effects of M\&As on Brazilian banks, especially on the rival banks of recentlymerged ones, which is less frequently addressed in the Brazilian literature.

\subsection{M\&A Waves Hypothesis}

This hypothesis is based on the conception that the decisions for companies to merge do not derive from the economic gains that are intrinsic to the events, such as synergistic gains, but from the market's tendency to become more concentrated (Chiang \& Zheng, 2010). 
This debate features the work of Song and Walkling (2000), who calculate the positive abnormal returns of rival companies of M\&A targets based on the greater probability of these events occurring. The reason, according to the authors, is the tendency for M\&A events, and not synergistic gains. Thus, shareholders anticipate M\&A events and heat the market for shares in companies that could possibly be acquired. In this context, Hankir et al. (2011) determine that in the analysis of peers rival companies, that is, the firms that are not directly involved in the M\&A process - a possible emergence of the "M\&A wave" theory is observed. Also according to the authors, any negotiation can increase market heating and, with this, the probability that all banks could be possible M\&A targets.

Due to the M\&A waves hypothesis, the market reaction mechanisms are expected to be volatile to the event. According to Hankir et al. (2011), the stock market's reaction to the event could be negative, if shareholders encounter some problems in these negotiations, such as agreements that generate excess payments (especially in heated markets), high costs of achieving post-merger synergies, and a lack of economic viability of the mergers. Also, for Song and Walkling (2000), shareholders heat the market and generate greater returns. It is perceived, with this, that the pricing of acquiring banks' assets tends to experience positive impacts with M\&A events, as well as the pricing of acquiring banks (M\&A waves hypothesis).

\subsection{Theoretical Model (Functional Relationship)}

In the first stage in the study of the M\&A waves hypothesis, the effect of these events both on the rivals of acquiring banks and on the rivals of acquired banks are observed, separately. The events in which the mergers were complete, pending, and complete and pending together were also observed. These M\&As were analyzed on their announcement dates. In addition, an analysis was carried out of the effective dates of the bank M\&As, that is, after the regulatory bodies' approval. These mergers aim to address, in separate studies, the effects over the pricing of the acquiring and acquired banks.

The second stage of the analysis adopts the idea that cumulative abnormal returns (CARs) are employed with more significant tests as the dependent variable in relation to the mean of the post-merger indicators (independent variables). However, in the case of this hypothesis, the average CARs of the rival banks are used as a dependent variable, and the average postmerger indicators of the banks directly involved are used as independent variables. The aim is to observe whether the market is more heated due to the M\&As and, with this, observe whether the investors of the rival banks manage to predetermine the average post-merger indicators of the banks directly involved in M\&As. The second stage analysis applies to the events that were really implemented, considering the M\&A announcement date.

This article uses the event study econometric model, in the first stage, to test the M\&A waves hypothesis. For the hypothesis to be evaluated, the CAR method is used with the aim of examining the short term effects of the bank M\&A events. In this case, four equilibrium return models are employed, these being: the constant means model, the market index model, the market model, and the capital asset pricing model (CAPM) suggested by Sharpe (1964) and Lintner (1965). In a second stage, the results of the abnormal returns found in the first stage are applied in relation to the post-merger accounting data (fundamentals analysis); in this case, the aim is to determine whether the results of the abnormal returns are able to predetermine the average performance and post-merger risk indicators. For the second stage of the article the quantile regression econometric tool is used. The mean indicators were determined between 4 and 5 years after the merger, used following a similar approach to the article by Duso, Gugler, and Yurtoglu (2010), which uses a similar analysis of the mean of the profitability indicators up to 5 years post-merger. The threshold value of 4 years was determined following Sherman and Rupert (2006), who state that bank M\&As are only completed in the 4 th year after the event is carried out.

\section{ANALYSIS METHODOLOGY}

This stage presents the population, the sample definition, the variables used in the study, the data source, the descriptive statistics of the data, and the econometric model. 


\subsection{Data Source, Population, and Sample Definition}

This article uses as a data source the financial data portal Datastream Advance, from Thomson Reuters. The sample collected from the portal emerged using the SIC (sector code) filter of codes 6000 to 6289 and code 6712 , used by Hankir et al. (2011). These codes represent the banking sector firms. In this study, the aim was to research Brazilian bank M\&As, analyzing the Brazilian stock market for bank
M\&As in the period from 2005 to 2015, which covers the availability of the data in the database mentioned.

In this study, the publicly-traded banks listed on the stock exchange were used. Twenty-six banking assets are operated, including ordinary, preference, and unit shares. In the sample, investment, commercial, and multiple banks are used. Among these, the sample contemplates public and private banks and those based in Brazil and overseas, totaling 15 banks. Table 1 describes the 26 assets used in the sample.

Table 1

Banking assets listed on the stock exchange

\begin{tabular}{cc}
\hline \multicolumn{2}{c}{ Banking financial assets listed on the BM\&FBOVESPA } \\
\hline Banco Abc Brasil PN & Banco Indusval ON \\
\hline Banco do Brasil ON & Banco Indusval PN \\
\hline Banco Bradesco ON & Itaúsa Investimentos ON \\
\hline Banco Bradesco PN & Itaúsa Investimentos PN \\
\hline BTG Pactual (BSP) Unit & Itaú Unibanco Holding ON \\
\hline Baneste Banco Espírito Santo ON & Itaú Unibanco Holding PN \\
\hline Baneste Banco Espírito Santo PN & Banco Pine PN \\
\hline Banco Mercantil do Brasil ON & Alfa Holdings ON \\
\hline Banco Mercantil do Brasil PN & Banco Santander ON \\
\hline Mercantil Investimentos PN & Banco Santander PN \\
\hline Banco Patagônia BDR (BSP) & Banco Santander Brasil Unit \\
\hline Banco Alfa de Investimentos PN & Banco Sofisa PN \\
\hline Banco Daycoval PN & Paraná Banco PN
\end{tabular}

BM\&FBOVESPA = São Paulo Stock, Commodities, and Futures Exchange.

Source: Elaborated by the authors.

Forty-three M\&A events between the 26 banking assets in the period from 2005 to 2015 were considered, these events being between Brazilian banks and Brazilian and foreign ones.

For the market evaluation, the market indices also extracted from the Datastream Advance database from Thomson Reuters were operationalized. The risk-free interest rate was retrieved from the Center for Custody and Financial Settlement of Private Securities (CETIP) database.

\subsection{Definition of the Study Variables}

When studying the impact of the bank M\&A events, the daily prices of the financial securities of the banks (Table 1) were used in accordance with Houston and Ryngaert (1994), Campa and Hernando (2006), Delong and DeYoung (2007), Hagendorff et al. (2008), Hankir et al. (2011), Asimakopoulos and Athanasoglou (2013), and Andriosopoulos and Yang (2015). As market variables, the São Paulo Stock, Commodities, and Futures Exchange (BM\&FBOVESPA) indices (Ibovespa) were used and the $\mathrm{BM} \& \mathrm{FBOVESPA}$ financial index (IFNC) was employed as the banking sector portfolio. As the risk-free interest rate, the Special System for Settlement and Custody (Selic) was used. All the assets, indices, and rates have daily periodicity.

The windows that study the bank M\&A events are 20 days prior to the announcement, the day of the announcement, and 20 days after the announcement; 15 days prior to the announcement, the day of the announcement, and 15 days after the announcement; and 10 days prior to the announcement, the day of the announcement, and 10 days after the announcement. It is worth noting that the 41-day window was used to determine the abnormal returns in the study by Asimakopoulos and Athanasoglou (2013); this window size is warranted by the fact that longer windows than this can include other events and shorter windows than this may not cover the whole impact resulting from the 
M\&A. The paper by Cummins, Lewis, and Wei (2006) used the 31-day window, but applicable to operating loss events. The studies by Delong and DeYoung (2007) used the 21-day window to determine M\&A events. In the banking M\&As, the dates of the public announcement and effective dates of these mergers are used.

The variable used in the study of the effects on the pricing of the assets are their returns; this mechanism is important for guaranteeing the stationarity of the historical financial series of the asset prices and of the indices. To calculate the returns on the assets the continuous returns method is used, which is:

$$
R_{i t}=\operatorname{Ln}\left(P_{i t}\right)-\operatorname{Ln}\left(P_{i t-1}\right)
$$

in which $\operatorname{Ln}\left(P_{i t-1}\right)$ is the natural logarithm of the price of asset $i$ in period $t-1$ and $\operatorname{Ln}\left(P_{i t}\right)$ is the natural logarithm of the price of asset $i$ in period $t$.

The article's second stage of analysis [section $2.2-$ Theoretical Model (Functional Relationship)] covers the post-estimation (ex-post) analysis of the M\&A events. For this, accounting indicators that represent the performance and operational risks of the banks involved are gathered, as well as control variables. The inputs for the calculation of the indicators and control variables were extracted from the Datastream Advance database, from Thomson Reuters, which has quarterly periodicity in the period from 2002 to 2015. The data are from the audited balance sheets retrieved from the consolidated financial statements and are in million reais.

The operational performance indicators are represented by the ROA (return on assets) (equation 2) and by the ROE (return on equity) (equation 3 ), both calculated according to the proposal by Lown, Osler, Strahan, and Sufi et al. (2000):

$$
R O A_{i t}=\frac{2 \pi_{i t}}{\left(T A_{i t}+T A_{i t-1}\right)}
$$

in which $\pi_{i t}$ is the net income after tax of bank $i$ in period $t, T A_{i t}$ is the total assets of bank $i$ in period $t$, and $T A_{i t-1}$ is the total assets of bank $i$ in period $t-1$. A similar analysis is carried out for the ROE:

$$
R O E_{i t}=\frac{2 \pi_{i t}}{\left(E_{i t}+E_{i t-1}\right)}
$$

in which $E_{i t}$ represents the total own capital of bank $i$ in period $t$ and $E_{i t-1}$ represents the total own capital of bank $i$ in period $t-1$.

The ROA indicator represents the operational performance of bank $i$ in period $t$ and the ROE indicator represents the shareholder performance of bank $i$ in period $t$. The performance indicators are in relation to the current quarter $(t)$ and the quarter immediately before $(t-1)$.
In the ex-post analysis, Houston and Ryngaert (1994), Delong and DeYoung (2007), and Andriosopoulos and Yang (2015) used the ROA indicator. The ROE indicator, in this case ex-post, was used by Campa and Hernando (2006), Delong and DeYoung (2007), Hagendorff et al. (2008), and Hankir et al. (2011). In all the cases analyzed, these indicators represented the banks' post-merger performance. The greater the bank's performance is, the greater the indicator will be.

As an operational risk indicator, the Z-score similar to that of Lown et al. (2000) and Tabak et al. (2013) is used. According to Lown et al. (2000), this indicators represents the probability of a bank failing:

$$
z-\text { Score }_{i t}=\frac{R O A_{i t}+E Q A S_{i t}}{\sigma_{R O A_{i}}}
$$

in which EQAS represents the relationship between the total own capital and total assets of bank $i$ in period $t$ and $\sigma R O A_{i}$ is the standard deviation (SD) of bank $i$. According to equation 4 , the greater the $\mathrm{Z}$-score value, the lower the probability of bank i failing. For Tabak et al. (2013), the Z-score indicator is a risk measure accepted by the literature.

For control variables, the natural logarithm of the total assets of bank $i$ in period $t$ was used as a proxy for the size of bank $i$. The logarithm of assets control variable was used by Delong and DeYoung (2007) and Hankir et al. (2011). For Delong and DeYoung (2007), big banks tend to present few post-merger gains.

Another control variable used is the relative share of bank $i$ in the sector. Equation 5 is an adaptation from Hax and Majluf (1983) that uses total assets as a decision variable. This variable represents relative share and is measured by the ratio between the total assets of company $i$ in period $t$ and the maximum value of total assets of period $t$ of a particular sector. The relative share is the ratio between the size of company $i$ in relation to the market leading company:

$$
\text { Rel.Sh }_{i t}=\frac{T A_{i t}}{T A_{t}^{*}}
$$

in which $T A^{*}$ is the maximum total assets in period $t$, representing the leading company of the banking sector. That is, the ratio between the total assets of bank $i$ in period $t$ and the total assets of the segment leading bank $T A^{*}$ is a relative measure of the market concentration. The aim of the market concentration indicators is to identify the competitive strength of the business environment in which the firm operates. The relative share measure determines the fragmentation of the industry and is a relative measure of the internal strength of the business (Hax \& Majluf, 1983). In this measure, the closer the relative share measure is 
to 1 , the greater the market power of bank $i$ in period $t$.

The last control variable used is the M\&A negotiation value. This variable was used in the paper by Hagendorff et al. (2008). According to these authors, the size of the business is a proxy for the degree of market power. The greater the value of the business, the greater the market power of the acquiring firm and the more heated the market is.

Table 2 summarizes the use of each ex-post variable, its meaning, and the main sources used for choosing it.

Table 2

Ex-post variables (post-estimation)

\begin{tabular}{|c|c|c|}
\hline Variable & Meaning & Source \\
\hline $\mathrm{ROA}$ & $\begin{array}{l}\text { Operational } \\
\text { performance }\end{array}$ & $\begin{array}{l}\text { Houston and Ryngaert (1994), } \\
\text { Delong and DeYoung (2007), } \\
\text { Andriosopoulos and Yang (2015) }\end{array}$ \\
\hline ROE & $\begin{array}{l}\text { Shareholder } \\
\text { performance }\end{array}$ & $\begin{array}{c}\text { Campa and Hernando (2006), } \\
\text { Delong and DeYoung (2007), } \\
\text { Hagendorff et al. (2008), } \\
\text { Hankir et al. (2011) }\end{array}$ \\
\hline Z-score & $\begin{array}{c}\text { Operational } \\
\text { (accounting) risk }\end{array}$ & $\begin{array}{l}\text { Lown et al. (2000), } \\
\text { Tabak et al. (2013) }\end{array}$ \\
\hline Ln assets & Size of the bank & $\begin{array}{c}\text { Delong and DeYoung (2007), } \\
\text { Hankir et al. (2011) }\end{array}$ \\
\hline $\begin{array}{l}\text { Relative } \\
\text { share }\end{array}$ & Market concentration & Hax and Majluf (1983) \\
\hline $\begin{array}{l}\text { M\&A } \\
\text { value }\end{array}$ & $\begin{array}{l}\text { Degree of market } \\
\text { power and heating }\end{array}$ & Hagendorff et al. (2008) \\
\hline
\end{tabular}

$M \& A=$ mergers and acquisitions.

Source: Elaborated by the authors.

\subsubsection{Stationarity of the financial series}

With the aim of estimating the equilibrium or benchmark returns (Brown \& Warner, 1980, 1985), stationarity tests of the series of bank security returns were carried out, as well as of the market indices used in this research (IFNC and Ibovespa). The test used is the augmented Dickey-Fuller unit root test (Dickey \& Fuller, 1979), which has as its null hypothesis the determination of a unit root in the series studied. To increase the precision of the stationarity of the returns analysis, the Phillips and Perron (1988) test is used, which makes a non-parametric correction to the DickeyFuller test, enabling it to be consistent, even if there are dependent lagged variables and serial correlation in the errors. Another calculation method used to guarantee the stationarity of the series of returns is the DickeyFuller generalized least squares (DF-GLS) test proposed by Elliott, Rothenberg, and Stock (1996), in which the authors argue that the power of the Dickey-Fuller test can be increased if, somehow, the deterministic terms are purged from the regression of the test.

Table 3 presents the stationarity tests for each series of returns on the securities, as well as the market indices used to estimate the equilibrium returns on the bank asset prices.

Table 3

Stationarity tests for the returns

\begin{tabular}{|c|c|c|c|c|c|c|}
\hline \multicolumn{7}{|c|}{ Tests for unit root } \\
\hline Asset/index & $\begin{array}{l}\text { Statistics of } \\
\text { the augmented } \\
\text { Dickey-Fuller } \\
\text { Z(t) test } \operatorname{lag}(0)\end{array}$ & $\begin{array}{c}\text { P-value } \\
\text { Mackinnom } \\
\text { approximation }\end{array}$ & $\begin{array}{l}\text { Statistics of the } \\
\text { Phillips-Perron } \\
\text { Z(t) test }\end{array}$ & $\begin{array}{c}\text { P-value } \\
\text { Mackinnom } \\
\text { approximation }\end{array}$ & $\begin{array}{l}\text { Statistics of the } \\
\text { DF-GLS test lag(0) }\end{array}$ & $\begin{array}{l}\text { Asymptotic } \\
\text { p-value }\end{array}$ \\
\hline Banco Abc Brasil PN & -40.202 & $0^{* *}$ & -40.232 & $0 * *$ & -34.937 & $0 * *$ \\
\hline Banco do Brasil ON & -73.86 & $0 * *$ & -73.885 & $0 * *$ & -24.685 & $0^{* *}$ \\
\hline Banco Bradesco ON & -74.253 & $0 * *$ & -74.21 & $0^{* *}$ & -76.92 & $0^{* *}$ \\
\hline Banco Bradesco PN & -73.449 & $0 * *$ & -73.449 & $0 * *$ & -77.278 & $0 * *$ \\
\hline BTG Pactual (BSP) - Unit & -24.519 & $0^{* *}$ & -24.475 & $0 * *$ & -25.364 & $0 * *$ \\
\hline Baneste Banco Espírito Santo ON & -79.29 & $0 * *$ & -81.057 & $0 * *$ & -76.057 & $0 * *$ \\
\hline Baneste Banco Espírito Santo PN & -46.007 & $0 * *$ & -46.355 & $0 * *$ & -11.17 & $0 * *$ \\
\hline Banco Mercantil do Brasil ON & -67.714 & $0 * *$ & -67.933 & $0 * *$ & -77.231 & $0 * *$ \\
\hline Banco Mercantil do Brasil PN & -71.453 & $0 * *$ & -71.688 & $0 * *$ & -76.126 & $0 * *$ \\
\hline Mercantil Investimentos PN & -75.515 & $0 * *$ & -76.888 & $0 * *$ & -13.218 & $0 * *$ \\
\hline Banco Patagônia BDR (BSP) & -38.403 & $0 * *$ & -38.621 & $0 * *$ & -29.025 & $0 * *$ \\
\hline Banco Alfa Investimentos PN & -69.592 & $0 * *$ & -69.716 & $0^{* *}$ & -77.972 & $0^{* *}$ \\
\hline Banco Daycoval PN & -42.45 & $0 * *$ & -42.482 & $0 * *$ & -42.941 & $0 * *$ \\
\hline Banco Indusval ON & -39.973 & $0 * *$ & -40.084 & $0 * *$ & -41.201 & $0 * *$ \\
\hline Banco Indusval PN & -45.727 & $0 * *$ & -45.651 & $0 * *$ & -32.177 & $0 * *$ \\
\hline Itausa Investimentos ON & -71.012 & $0 * *$ & -71.346 & $0 * *$ & -82.785 & $0 * *$ \\
\hline Itausa Investimentos PN & -66.333 & $0 * *$ & -66.34 & $0 * *$ & -43.776 & $0 * *$ \\
\hline Itaú Unibanco Holding ON & -73.35 & $0^{* *}$ & -73.37 & $0^{* *}$ & -81.463 & $0 * *$ \\
\hline Itaú Unibanco Holding PN & -64.635 & $0 * *$ & -64.65 & $0 * *$ & -69.329 & $0^{* *}$ \\
\hline
\end{tabular}


Table 3

Cont.

\begin{tabular}{|c|c|c|c|c|c|c|}
\hline \multicolumn{7}{|c|}{ Tests for unit root } \\
\hline Asset/index & $\begin{array}{l}\text { Statistics of } \\
\text { the augmented } \\
\text { Dickey-Fuller } \\
\text { Z(t) test lag(0) }\end{array}$ & $\begin{array}{c}\text { P-value } \\
\text { Mackinnom } \\
\text { approximation }\end{array}$ & $\begin{array}{l}\text { Statistics of the } \\
\text { Phillips-Perron } \\
\text { Z(t) test }\end{array}$ & $\begin{array}{c}\text { P-value } \\
\text { Mackinnom } \\
\text { approximation }\end{array}$ & $\begin{array}{l}\text { Statistics of the } \\
\text { DF-GLS test lag(0) }\end{array}$ & $\begin{array}{c}\text { Asymptotic } \\
\text { p-value }\end{array}$ \\
\hline Banco Pine PN & -42.251 & $0^{* *}$ & -42.248 & $0^{* *}$ & -42.928 & $0^{* *}$ \\
\hline Alfa Holdings ON & -76.058 & $0^{* *}$ & -76.169 & $0^{* *}$ & -86.936 & $0^{* *}$ \\
\hline Banco Santander ON & -54.331 & $0^{* *}$ & -55.391 & $0^{* *}$ & -23.804 & $0^{* *}$ \\
\hline Banco Santander PN & -55.723 & $0^{* *}$ & -56.811 & $0^{* *}$ & -62.782 & $0 * *$ \\
\hline Banco Santander Brasil Units & -36.102 & $0^{* *}$ & -36.105 & $0^{* *}$ & -40.968 & $0 * *$ \\
\hline Banco Sofisa PN & -46.194 & $0^{* *}$ & -46.276 & $0^{* *}$ & -8.686 & $0 * *$ \\
\hline Paraná Banco PN & -41.722 & $0^{* *}$ & -41.819 & $0^{* *}$ & -42.34 & $0^{* *}$ \\
\hline IFNC & -47.81 & $0^{* *}$ & -47.757 & $0^{* *}$ & -36.015 & $0 * *$ \\
\hline Bovespa Index & -74.412 & $0^{* *}$ & -74.266 & $0^{* *}$ & -3.408 & $0^{* *}$ \\
\hline Augmented Dickey-Fuller & \multicolumn{3}{|c|}{ Phillips-Perron } & \multicolumn{2}{|c|}{ DF-GLS } & \\
\hline${ }^{* *}$ Critical value $1 \%$ & -3.43 & $\begin{array}{l}{ }^{* *} \text { Critical } \\
\text { value } 1 \%\end{array}$ & -3.43 & $\begin{array}{l}{ }^{* *} \text { Critical } \\
\text { value } 1 \%\end{array}$ & -2.58 & \\
\hline$*$ Critical value $5 \%$ & -2.86 & ${ }^{*}$ Critical value $5 \%$ & -2.86 & ${ }^{*}$ Critical value $5 \%$ & -1.956 & \\
\hline
\end{tabular}

Source: Elaborated by the authors.

The series of logarithmic returns on the prices $\left(R_{i t}\right)$ (equation 3) presented stationarity in all the securities listed in Table 3 and in the indices mentioned. With this, there is the possibility of estimating the series of returns on the assets.

\subsubsection{Description of the ex-post variables}

Table 4 presents a descriptive analysis of the postestimation variables. It shows the mean values, the median, the maximum and minimum values, the SD, and the coefficient of variation of the ex-post indicators (independent variables of the model).

Table 4

Description of the ex-post (post-estimation) variables

\begin{tabular}{cccccccc}
\hline Variables & Mean & Median & Maximum & Minimum & SD & $\begin{array}{c}\text { CV } \\
(\%)\end{array}$ & $\begin{array}{c}\text { Observations } \\
(\mathbf{n})\end{array}$ \\
\hline ROA (\%) & 0.55 & 0.44 & 8.06 & -18.36 & 1.07 & 51.11 & 891 \\
\hline ROE (\%) & 3.96 & 4.46 & 40.65 & -402.12 & 14.87 & 26.62 & 891 \\
\hline Z-score & 46.75 & 44.23 & 182.54 & -3.60 & 33.20 & 140.81 & 885 \\
\hline Ln assets & 9.87 & 9.35 & 14.27 & 4.33 & 2.27 & 434.03 & 878 \\
\hline Rel. share (\%) & 22.36 & 1.35 & 100.00 & 0.00 & 33.85 & 66.06 & 879 \\
\hline $\begin{array}{c}\text { Value of the M\&A } \\
\text { (million USD) }\end{array}$ & 536.96 & 138.27 & $2,249.70$ & 6.00 & 871.38 & 61.62 \\
\hline Note: The vara & & & & & 43 \\
\hline
\end{tabular}

Note: The variables are described in Table 2.

$C V=$ coefficient of variation; $S D=$ standard deviation; $M \& A=$ mergers and acquisitions.

Source: Thomson Reuters.

\subsection{Econometric Models}

\subsubsection{Econometric models of events study}

The event study examines the behavior of the returns for a sample of firms that experience a particular event in common, as in the case of M\&As. The event could take place on different calendar dates. However, in the analysis, the initial date is the date of the occurrence of the event (Kothari \& Warner, 2007).

In the event studies method, the initial task is to determine the event that will be analyzed, known as the event of interest or focal event. After determining the focal event, the event temporal window is determined, that is, the period during which the asset prices of the companies studied will be analyzed. In practice, the period of interest is often extended to various days, including, necessarily, the day of the event.

In general, day " 0 " is defined as the day of the event of interest for each asset, with daily periodicity. For daily returns, the 252 days ( 1 working year) before the date of the share return focal event were analyzed, known as the estimation period. The first 41 days around the event 
of interest (-20 to 20), including the date of the event of interest, are called the event period (depending on the window of the event to be considered). According to Brown and Warner (1985), for the asset to be included in the sample, it should have at least 30 daily returns in the data for the estimation period and 20 days of nonnull daily returns.

To evaluate a focal event, a measure of abnormal return is needed. This is defined as the difference between the observed return of asset $i$ in period $\tau$ and the expected normal return (predictor) of the financial asset in the temporal window $\tau$ (MacKinlay, 1997). For bank $i$ in period $\tau$ in which the event of interest occurs (focal event), the abnormal return is given by:

$$
A R_{i \tau}=R_{i \tau}-E\left(R_{i \tau} \mid f_{\tau}\right)
$$

in which $A R_{i \tau}$ is the abnormal return, $A R_{i \tau}$ is the observed return on financial asset $i$ in period $\tau$, and $E\left(R_{i \tau} \mid f_{\tau}\right)$ is the conditional expectation of the normal return conditioned to the information set $f_{\tau}$ for the period specified, also called the predictor. There are various models listed by the literature that measure expected returns, including those presented below.

\subsubsection{CAR Calculations}

Brown and Warner $(1980,1985)$ present three models for measuring abnormal returns. For the authors, only an observed return that will be compared with a benchmark return, that is, with an estimated return, can be considered "abnormal".

This article uses three versions of estimated return from Brown and Warner $(1980,1985)$ that, according to MacKinlay (1997), represent the compilation of statistical models for equilibrium returns: the mean-adjusted returns version (model 1), the market index returns version (model 2), and the market model version with two forms of estimation (models 3 and 4). A fourth estimated returns version is also proposed, which corresponds to the CAPM model developed by Sharpe (1964) and Lintner (1965). In this case, for MacKinlay (1997), this is an equilibrium returns economic model (model 5).

The models that presented the most expressive results were the ones widely used in the literature, these being: the constant mean models (model 1) and the market model with ordinary least squares (OLS) estimation (model 3 ). These models can be found, for example, in Song and Walkling (2000), Delong and DeYoung (2007), and Hankir et al. (2011).

The constant means return model (model 1) is the calculation of the mean of the returns observed during the estimation period and its extrapolation to determine the estimated (benchmark) return.

$$
E\left(R_{i \tau}\right)=\overline{R_{i \tau}}=\frac{1}{n} \sum_{T_{0}}^{T_{1}} R_{i \tau}
$$

in which $R_{i \tau}$ is the observed return on asset $i$ in period $\tau$, and $\overline{R_{i \tau}}$ is the mean of the returns observed during the estimation period $\left(T_{0}-T_{1}\right)$.

The market index model (model 2) is the one that establishes a market index, in the Brazilian case the Ibovespa as $R_{m i}$ :

$$
A R_{i \tau}=R_{i \tau}-R_{m \tau}
$$

The market model is the method that uses the CAPM basis presented by Sharpe (1964), in which the estimated market return is:

$$
E\left(\hat{R}_{i \tau}\right)=\hat{\alpha}+\hat{\beta} * E\left(R_{m \tau}\right)
$$

in which $\hat{\alpha}$ and $\hat{\beta}$ are estimated parameters of the market model, $E\left(\hat{R}_{i \tau}\right)$ is the expectation for estimated returns on the assets by the market model, and $E\left(R_{m \tau}\right)$ is the expectation for the observed returns on the market indices (in this case the Ibovespa). The estimation of the parameters $\hat{\alpha}$ and $\hat{\beta}$ will be carried out using the ordinary least squares (OLS) method (model 3) and the non-synchronized data estimation method of Scholes and Williams (1977) (model 4 ). The second model is ideal for daily data, that is, when non-synchronized data problems can occur.

In the CAPM model (model 5) presented by Sharpe (1964) and Lintner (1965), the estimated return is:

$$
E\left(\hat{R}_{i \tau}\right)=R_{f \tau}+\hat{\beta} * E\left(R_{m \tau}-R_{f \tau}\right)
$$

in which $R_{f t}$ is the return on the risk-free asset, in this study the Selic rate, the parameter is the estimated parameter of the CAPM model, $E\left(\hat{R}_{i \tau}\right)$ is the expectation for estimated returns on the assets of the CAPM, and $E\left(R_{m \tau}\right)$ is the expectation for the observed returns on the market indices (Ibovespa).

\subsubsection{Statistical tests of the abnormal returns}

To analyze the statistical significance of the abnormal returns it is necessary to use statistical hypothesis tests. This section proposes some tests to determine the existence of abnormal returns arising from bank M\&A events in M\&A waves.

According to Corrado (2011), a common assumption is that abnormal returns follow a normal distribution. This assumption is used in determining the statistical significance tests. However, according to Brown and Warner (1985), daily returns do not behave in a similar way to monthly returns.

With this, four tests are used, as well as the Student $t$ tests ( $t$ in cross-section and $t$ in time-series), to obtain the significances of the abnormal returns. For greater robustness of the results, the Patell $z$ hypothesis test (Patell, 
1976) is carried out. The idea is the same as the classic Student $t$ test, in which, under the null hypothesis, the cumulative abnormal returns will be 0 and the mean of the abnormal returns over the deviations of the cumulative abnormal returns will follow a Student $t$ distribution. According to Patell (1976), this analysis mechanism purges the heteroskedasticity that could be found in the estimation of the abnormal returns.

Another method that will add to the analysis of the cumulative abnormal returns is the cross-section test of the standard error of the abnormal returns developed by Boehmer, Musumeci, and Poulsen (1991) (test presented in the result tables in section 4 as Boehmer et al.). In this test, the correction of the serial correlation proposed by Kolari and Pynnönen (2010) is used. This method corrected by the serial correlation according to Boehmer et al. (1991) and Kolari and Pynnönen (2010) is interesting as it is a more robust test in the presence of high variations of the abnormal returns close to the dates of the events.

The aim is to carry out non-parametric tests in order to provide greater robustness concerning the data that diverge from normality. A non-parametric test that is used quite a lot in event studies is the one proposed by Corrado (2011). This test is known as the Corrado rank, in which Corrado (2011) defines a rank of statistics to establish the deviations from the null hypothesis $\left(H_{0}\right)$, in which the cumulative abnormal returns are equal to zero.

The last test to be carried out is the non-parametric one from Cowan (1992), known as the general sign test, based on the ratio of the numbers of positive abnormal returns around the window of events. Under the null hypothesis $\left(H_{0}\right)$, the ratio of positive abnormal returns should not deviate from the estimated ratio of positive returns of the window of events. In this test, the distribution of the ratio of positive abnormal returns will converge to the binominal distribution.

\subsubsection{Quantile regression econometric model}

The quantile regression originates from the work of Koenker and Bassett (1978), in which the authors use the idea of conditional estimation of the quantile functions as a basis. These models present a relationship in which the quantiles of the conditional distribution of the dependent variable are expressed in terms of independent covariates. For Koutsomanoli-Filippaki, Mamatzakis, and Pasiouras (2013), the quantile regression is a statistical technique that aims to estimate and infer the conditional performance of the quantile functions. This analysis is particularly useful when the conditional distribution of the dependent variable does not have a known format, such as an asymmetric format of the distributions, long tails, or truncated distributions; such distributions are common to abnormal returns data (Koutsomanoli-Filippaki et al., 2013).

The quantile regression is useful in the presence of heteroskedasticity (Behr, 2010; Koutsomanoli-Filippaki et al., 2013). According to Koutsomanoli-Filippaki et al. (2013), this statistical tool is applicable to data that estimate the behavior of the stock market. This type of tool is interesting when the aim is to find the causal impact of the abnormal returns, due to their correction of data with heteroskedasticities.

The quantile regression is presented in the following form (Koutsomanoli-Filippaki et al., 2013):

$$
y_{i}=x_{i} \beta_{\phi}+\varepsilon_{i \phi}
$$

in which $\phi \epsilon(0,1), x_{i}$ is the vector $(K x 1)$ of regressors, $\beta \phi$ represents the angular coefficient of the conditional ratio of $y$ in relation to $x$ of the $\phi^{\text {th }}$ quantile, and $\varepsilon_{\phi}$ corresponds to the random error of the conditional quantile distribution. The $\phi^{\text {th }}$ quantile of the regression, $0<\phi<1$, is defined as a minimization solution to the following problem (Koenker \& Bassett, 1978):

$$
\min _{b \in R^{k}}\left[\sum \phi\left|y_{i}-x_{i} \beta\right|_{i \in\left\{i: y_{i} \geq x_{i} \beta\right\}}+\sum(1-\phi)\left|y_{i}-x_{i} \beta\right|_{i \in\left\{i: y_{i}<x_{i} \beta\right\}}\right]
$$

In this paper, $y_{i}$ corresponds to $C A R_{i}, x_{i}$ are the means up to 4 or 5 years of the post-merger indicator, excluding only the merger value, and the $\phi^{\text {th }}$ quantiles used are 25 , 50 (median), and $75 \%$. The quantile regression models are expressed regressing the whole set of variables $x_{i}$ (postmerger indicators) and the indicators separately, thus avoiding erroneous measurements due to the problem of multicollinearity in the data (measurement via variance inflation factor).

According to Delong and DeYoung (2007), Hagendorff et al. (2008), and Duso et al. (2010), the individual cumulative abnormal returns of each bank $i$ are timeless and, therefore, can be regressed to the post-merger indicators. These indicators, when used in their average format of M\&A event integralization time, are also treated as timeless, thus resulting in a cross-sectional estimation of the abnormal returns in relation to the post-merger indicators. This mechanism, as Delong and DeYoung (2007) state, is adequate for observing market efficiency in its semistrong format. 


\section{EMPIRICAL ANALYSIS AND DISCUSSION OF THE RESULTS}

\subsection{Hypothesis - Bank M\&A Waves}

\subsubsection{Announcement date of bank M\&A events (concrete and pending)}

The first step is to analyze the M\&A events in the rivals (peers) of the acquiring banks, a methodology employed by Hankir et al. (2011). This field of analysis works with the date of the announcement of implemented and pending bank M\&As. Table 5 presents the reaction of the investors of the rival banks of the acquiring ones to the events mentioned.

Table 5

Date of announcement of bank mergers and acquisitions (M\&As) in pending and implemented events

\begin{tabular}{|c|c|c|c|c|c|}
\hline & Model 1 & Model 2 & Model 3 & Model 4 & Model 5 \\
\hline CAR $(-20,+20)$ & -0.0067 & 0.0035 & 0.015 & -0.0139 & -0.0113 \\
\hline time-series t-test & 0.3211 & 0.5479 & $0.0219^{* *}$ & 0.2383 & $0.0836^{*}$ \\
\hline cross-sectional t-test & 0.3333 & 0.5027 & $0.0104^{* *}$ & 0.6421 & $0.0295^{* *}$ \\
\hline Patell z & $0.0063^{* * *}$ & $\mathrm{NA}$ & 0.1246 & $0.0707^{*}$ & $0.0106^{* *}$ \\
\hline Boehmer et al. & 0.3604 & 0.7695 & 0.5703 & 0.5302 & 0.3263 \\
\hline Corrado rank & 0.2089 & $0.0261^{* *}$ & $0.0439^{* *}$ & $0.0502 *$ & $0.0454^{* *}$ \\
\hline sign test & $0^{* * *}$ & 0.8842 & 0.206 & $0.0458^{* *}$ & 0.2659 \\
\hline Pos $\mid$ Neg & $468 \mid 430$ & $541 \mid 357$ & $404 \mid 353$ & $414 \mid 343$ & $373 \mid 384$ \\
\hline CAR $(-15,+15)$ & -0.0016 & 0.0109 & 0.0191 & -0.001 & -0.0008 \\
\hline time-series t-test & 0.7845 & $0.0328^{* *}$ & $0.0008^{* * *}$ & 0.9212 & 0.8859 \\
\hline cross-sectional t-test & 0.79 & $0.0288^{* *}$ & $0.0004^{* * *}$ & 0.9623 & 0.8665 \\
\hline Patell z & $0.0173^{* *}$ & NA & $0.0061^{* * *}$ & $0.002^{* * *}$ & 0.4094 \\
\hline Boehmer et al. & 0.4298 & 0.436 & 0.314 & 0.2704 & 0.7471 \\
\hline Corrado rank & $0.0781^{*}$ & $0.0115^{* *}$ & $0.0218^{* *}$ & $0.0218^{* *}$ & $0.0252^{* *}$ \\
\hline sign test & $0^{* * *}$ & 0.6897 & 0.695 & 0.1793 & 0.9836 \\
\hline Pos $\mid$ Neg & $450 \mid 448$ & $533 \mid 365$ & $392 \mid 365$ & $405 \mid 352$ & $358 \mid 399$ \\
\hline CAR $(-10,+10)$ & -0.0053 & 0.0069 & 0.0111 & -0.003 & -0.0023 \\
\hline time-series t-test & 0.2735 & 0.1004 & $0.0172 * *$ & 0.7221 & 0.6175 \\
\hline cross-sectional t-test & 0.3031 & 0.121 & $0.0165^{* *}$ & 0.8444 & 0.5943 \\
\hline Patell z & $0.0011^{* * *}$ & NA & 0.1174 & $0.063^{*}$ & 0.1752 \\
\hline Boehmer et al. & 0.2782 & 0.6363 & 0.5787 & 0.5269 & 0.6193 \\
\hline Corrado rank & $0.0423^{* *}$ & $0.0329 * *$ & $0.081^{*}$ & $0.0788^{*}$ & $0.0875^{*}$ \\
\hline sign test & $0^{* * *}$ & 0.8307 & 0.3302 & 0.5381 & 0.2359 \\
\hline Pos $\mid$ Neg & $459 \mid 439$ & $542 \mid 356$ & $400 \mid 357$ & $395 \mid 362$ & $374 \mid 383$ \\
\hline
\end{tabular}

Note: In this table, the cumulative abnormal return (CAR) refers to the mean of the CARs of each bank in the period analyzed.

$N A=$ non-argument.

$* * *, * *, *$ significance at 1,5 , and $10 \%$, respectively.

Source: Elaborated by the authors.

From Table 5, it is observed that the model chosen was the market one estimated by MQO/OLS (model 3 ) for questions of robustness of the analyses $(-15,+15$ window). This model presented the greatest number of statistical tests with significance. The choice of a model that has the greatest quantity of significant hypothesis tests arises from a robustness analysis of the results (see Statistical tests of abnormal returns section). These results are more robust in the presence of heteroskedasticity and in a possible non-normality of the CARs distribution, and these occurrences are common in finance. In Table 4 , it is observed that the economic-financial indicators of the banks analyzed present high variability, causing problems of heteroskedasticity, making the tails of the CARs distributions longer. In addition, this model was also used by Song and Walkling (2000) and Delong and DeYoung (2007). This model presents the market's relationship with the asset studied. With this analysis, it is observed that the signs of the mean cumulative abnormal returns are positive, independent of the window of events used. These results are consistent with the findings of Song and Walkling (2000). In this context, the investors of the rivals of the acquiring banks directly involved in bank M\&As positively price their banks' assets. This analysis 
occurs because, in heated markets, the probability of the rival banks becoming involved in M\&As increases (Song \& Walkling, 2000).

It is worth noting that, in some estimation models used to demonstrate robustness in the analysis, the results can be negative, which shows that, depending on the model used, the results can be different. Yet, in these robustness models, despite the average CAR being negative, the number of positive individual CARs is greater than the number of negative ones.

\subsubsection{Date of the announcement of bank M\&A events (concrete)}

The next step in the investigation of this hypothesis continues to work with the analysis of the M\&A events in the rivals (peers) of the acquiring banks, a methodology used by Hankir et al. (2011). This field of analysis works with the date of the announcement in actually implemented bank M\&As. Table 6 presents the reaction of the investors of the rivals of the acquiring banks to the events mentioned.

Table 6

Date of announcement of bank mergers and acquisitions (M\&As) in actually implemented events

\begin{tabular}{|c|c|c|c|c|c|}
\hline & Model 1 & Model 2 & Model 3 & Model 4 & Model 5 \\
\hline CAR $(-20,+20)$ & 0.0214 & 0.0038 & 0.0278 & -0.026 & -0.0072 \\
\hline time-series t-test & $0.0207^{* *}$ & 0.6205 & $0.0026^{* *}$ & 0.1785 & 0.438 \\
\hline cross-sectional t-test & $0.0412^{* *}$ & 0.6389 & $0.0017^{* *}$ & 0.6154 & 0.3589 \\
\hline Patell z & 0.838 & NA & $0.0635^{*}$ & $0.0859 *$ & $0.0263^{* *}$ \\
\hline Boehmer et al. & 0.9476 & 0.9414 & 0.5174 & 0.5844 & 0.4235 \\
\hline Corrado rank & 0.79 & $0.0626^{*}$ & $0.0738^{*}$ & 0.106 & $0.0708^{*}$ \\
\hline sign test & $0.0304^{* *}$ & 0.8269 & 0.1416 & $0.0481^{* *}$ & $0.0402^{* *}$ \\
\hline $\mathrm{Pos} \mid \mathrm{Neg}$ & $339 \mid 223$ & $353 \mid 209$ & $238 \mid 197$ & $243 \mid 192$ & $225 \mid 210$ \\
\hline CAR $(-15,+15)$ & 0.0405 & 0.0093 & 0.0344 & -0.0044 & 0.0079 \\
\hline time-series t-test & $0^{* * *}$ & 0.1613 & $0^{* * *}$ & 0.7947 & 0.3238 \\
\hline cross-sectional t-test & $0 * * *$ & 0.2234 & $0 * * *$ & 0.9061 & 0.2819 \\
\hline Patell z & $0.0042^{* * *}$ & NA & $0.0004^{* * *}$ & $0.0006^{* * *}$ & 0.9994 \\
\hline Boehmer et al. & 0.3412 & 0.7496 & 0.202 & 0.2391 & 0.9981 \\
\hline Corrado rank & 0.465 & 0.1093 & $0.0797^{*}$ & 0.1069 & $0.0819^{*}$ \\
\hline sign test & $0.0848^{*}$ & 0.2046 & 0.2371 & 0.0913* & 0.4796 \\
\hline Pos $\mid$ Neg & $344 \mid 218$ & $341 \mid 221$ & $235 \mid 200$ & $240 \mid 195$ & $211 \mid 224$ \\
\hline CAR $(-10,+10)$ & 0.0247 & 0.0044 & 0.0211 & -0.006 & 0.0032 \\
\hline time-series t-test & $0.0002^{* * *}$ & 0.4198 & $0.0014^{* * *}$ & 0.6635 & 0.6286 \\
\hline cross-sectional t-test & $0.0019^{* * *}$ & 0.5253 & $0.0035^{* * *}$ & 0.8193 & 0.6392 \\
\hline Patell z & 0.1324 & NA & $0.0448^{*}$ & $0.0543^{*}$ & 0.3664 \\
\hline Boehmer et al. & 0.6223 & 0.9834 & 0.4877 & 0.5311 & 0.7465 \\
\hline Corrado rank & 0.8912 & 0.3263 & 0.3422 & 0.389 & 0.3424 \\
\hline sign test & 0.309 & $0.0729 *$ & 0.322 & 0.5263 & 0.4796 \\
\hline Pos|Neg & $352 \mid 210$ & $335 \mid 227$ & $233 \mid 202$ & $229 \mid 206$ & $211 \mid 224$ \\
\hline
\end{tabular}

Note: in this table, the cumulative abnormal return (CAR) refers to the mean of the CARs of each bank in the period analyzed.

$N A=$ non-argument.

***, $* *, *$ significance at 1,5 , and $10 \%$, respectively.

Source: Elaborated by the authors.

The market model estimated by the MQO/OLS method (model 3) was the one chosen for the mean cumulative abnormal returns analysis. This model was adopted in the papers by Song and Walkling (2000) and Delong and DeYoung (2007). Observing Table 6 , it can be seen that in most of the models, positive average CAR values are presented and, in all the models tested, the signs of the positive individual CARs were greater than the negative ones. The result shows that the signs of the average cumulative abnormal returns are generally positive. This same result was found by Song and Walkling (2000). According to these authors, this analysis occurs because, in heated markets, the probability of the rival banks becoming involved in M\&As increases, leading to market gains and greater market power for the acquiring banks (Song \& Walkling, 2000).

In the post-merger analysis, quantile and interquantile regressions are used to observe the correlation between the CARs and the post-M\&A indicators. The results of the quantile regression in the $75 \%$ quantile, presented in Table 7, and of the interquantile regression, presented in Table 8 , showed that the ROA performance indicator is positive and significant. These results strengthen the 
heated market hypothesis. Faced with the mergers of their competitors, the investors of the rival banks were able to observe that these M\&As generated rising performance indicator values for the competitor banks in the period of 4 to 5 years after the M\&As. The ROE was shown to be significant in the quantile regression in the $25 \%$ quantile. In the other models, the results were shown not to have significance. These results are consistent with those found by Araújo et al. (2007), in which the authors observe that M\&As do not generate direct and quick values for the banks directly involved, showing that the M\&A waves and heated market hypothesis is observed in these types of operations. Another study that is consistent with this vision is that of Pessanha et al. (2012), in which the authors show that the gains over the return of banks that are directly involved in M\&As are of low intensity, which suggests that the abnormal returns of rival banks derive from a heated market process.

Table 7

Ex-post (post-estimation) quantile regression

\begin{tabular}{|c|c|c|c|c|c|c|c|c|c|c|c|}
\hline \multirow{2}{*}{$\begin{array}{c}\text { CAR }(-15,15) \\
\text { - Model } 3\end{array}$} & \multirow{2}{*}{$\begin{array}{c}\text { bsQreg1 } \\
\text { q25 }\end{array}$} & \multirow{2}{*}{$\begin{array}{c}\text { bsQreg2 } \\
\text { q50 }\end{array}$} & \multirow{2}{*}{$\begin{array}{c}\text { bsQreg3 } \\
\text { q75 }\end{array}$} & bsQreg4 & \multicolumn{2}{|c|}{ bsQreg5 } & bsQreg6 & bsQreg7 & \multirow{2}{*}{$\begin{array}{c}\text { bsQreg8 } \\
\text { q50 }\end{array}$} & \multirow{2}{*}{$\begin{array}{c}\text { bsQreg9 } \\
\text { q75 }\end{array}$} & \multirow{2}{*}{$\begin{array}{c}\text { bsQreg10 } \\
\text { q25 }\end{array}$} \\
\hline & & & & $q 25$ & q5 & & 75 & $q 25$ & & & \\
\hline \multirow{2}{*}{ ROA } & -2.98 & 9.62 & $45.50 * * *$ & -4.71 & 7.5 & & $12^{* *}$ & & & & \\
\hline & $(0.64)$ & $(0.20)$ & $(0.00)$ & $(0.44)$ & $(0.1$ & 18) & 05) & & & & \\
\hline \multirow{2}{*}{ ROE } & 1.74 & 1.08 & 1.62 & & & & & $1.27^{* *}$ & 0.39 & 0.50 & \\
\hline & $(0.25)$ & $(0.32)$ & $(0.32)$ & & & & & $(0.03)$ & $(0.45)$ & $(0.59)$ & \\
\hline \multirow{2}{*}{ Z-score } & 0.00 & 0.00 & $0.0024^{* *}$ & & & & & & & & 0.00 \\
\hline & $(0.38)$ & $(0.19)$ & $(0.01)$ & & & & & & & & $(0.22)$ \\
\hline \multirow{2}{*}{ LN assets } & $0.03 *$ & 0.00 & $-0.07^{* *}$ & & & & & & & & \\
\hline & $(0.06)$ & $(1.00)$ & $(0.03)$ & & & & & & & & \\
\hline \multirow{2}{*}{$\begin{array}{c}\text { M\&A value } \\
\text { (thousand USD) }\end{array}$} & 0.00 & 0.00 & 0.00 & & & & & & & & \\
\hline & $(0.85)$ & $(0.97)$ & $(0.13)$ & & & & & & & & \\
\hline \multirow{2}{*}{ Rel. share } & -0.14 & -0.04 & 0.25 & & & & & & & & \\
\hline & $(0.33)$ & $(0.70)$ & $(0.16)$ & & & & & & & & \\
\hline \multirow{2}{*}{ _cons } & $-0.49 * *$ & -0.09 & 0.40 & -0.03 & $-0 .($ & & .01 & $0.12^{* * *}$ & -0.01 & 0.07 & $-0.07^{* * *}$ \\
\hline & $(0.01)$ & $(0.67)$ & $(0.11)$ & $(0.33)$ & $(0.3$ & & 80) & $(0.00)$ & $(0.66)$ & $(0.20)$ & $(0.00)$ \\
\hline \multirow[t]{2}{*}{ Observations (n) } & 411 & 411 & 411 & 411 & 41 & & 11 & 411 & 411 & 411 & 411 \\
\hline & bsQreg11 & bsQreg12 & bsQreg13 b & bsQreg14 b & bsQreg15 & bsQreg16 & bsQreg17 & 7 bsQreg18 & 8 bsQreg19 & bsQreg20 & bsQreg21 \\
\hline $\begin{array}{c}\text { CAR }(-15,15) \\
- \text { Model } 3\end{array}$ & q50 & $q 75$ & q25 & q50 & $q 75$ & $q 25$ & q50 & $q 75$ & q25 & q50 & q75 \\
\hline \multicolumn{12}{|l|}{$\mathrm{ROA}$} \\
\hline \multicolumn{12}{|l|}{ ROE } \\
\hline \multirow{2}{*}{ Z-score } & 0.00 & $-0.0013^{*}$ & & & & & & & & & \\
\hline & $(0.72)$ & $(0.10)$ & & & & & & & & & \\
\hline \multirow{2}{*}{ LN assets } & & & $0.02^{* * *}$ & 0.01 & -0.00 & & & & & & \\
\hline & & & $(0.00)$ & $(0.35)$ & $(0.99)$ & & & & & & \\
\hline \multirow{2}{*}{$\begin{array}{c}\text { M\&A value } \\
\text { (thousand USD) }\end{array}$} & & & & & & & & & $-0,00$ & 0,00 & $0,00003^{* *}$ \\
\hline & & & & & & & & & $(0,58)$ & $(0,58)$ & $(0,01)$ \\
\hline \multirow{2}{*}{ Rel. share } & & & & & & $0.07^{*}$ & -0.00 & $-0,07$ & & & \\
\hline & & & & & & $(0.06)$ & $(0.95)$ & $(0,22)$ & & & \\
\hline \multirow{2}{*}{ _cons } & 0.01 & $0.15^{* * *}$ & $-0.34 * * *$ & -0.06 & 0.10 & $-0.10^{* * *}$ & 0.01 & $0,16^{* * *}$ & $-0,04 * * *$ & 0,01 & $0,07^{* * *}$ \\
\hline & $(0.65)$ & $(0.00)$ & $(0.00)$ & $(0.44)$ & $(0.59)$ & $(0.00)$ & $(0.62)$ & $(0,00)$ & $(0,00)$ & $(0,20)$ & $(0,00)$ \\
\hline Observations (n) & 411 & 411 & 411 & 411 & 411 & 411 & 411 & 411 & 411 & 411 & 411 \\
\hline
\end{tabular}

Notes: the variables are described in Table 2. Estimation of the standard error with bootstrapping.

$M \& A=$ mergers and acquisitions.

***, ${ }^{* *}, *$ significance at 1,5 , and $10 \%$, respectively.

Source: Elaborated by the authors.

Thus, the rival banks are expected to obtain a greater probability of mergers. This result derives from greater cumulative abnormal returns, since the investors of the rivals of the acquiring banks, in part, have managed to 
price the possible gains of these rival banks. These gains arose from the bank M\&As that really occurred, thus increasing the probability of M\&As in their banks, via a tendency to merge.

Table 8

Ex-post (post-estimation) interquantile regression

\begin{tabular}{|c|c|c|c|c|c|c|c|c|}
\hline $\begin{array}{c}\text { CAR }(-15,15) \\
\text { - Model } 3\end{array}$ & IQreg1 & IQreg2 & IQreg3 & IQreg4 & IQreg5 & IQreg6 & IQreg7 & IQreg8 \\
\hline \multirow{2}{*}{ ROA } & $48.47^{* * *}$ & $27.83^{* *}$ & & & & & & $31.46^{* * *}$ \\
\hline & $(0.00)$ & $(0.01)$ & & & & & & $(0.01)$ \\
\hline \multirow{2}{*}{ ROE } & -0.12 & & -0.77 & & & & & 2.11 \\
\hline & (0.95) & & $(0.36)$ & & & & & $(0.20)$ \\
\hline \multirow{2}{*}{ Z-score } & $0.0018^{*}$ & & & $-0.0018^{*}$ & & & & 0.00 \\
\hline & (0.08) & & & $(0.06)$ & & & & $(0.11)$ \\
\hline \multirow{2}{*}{$\mathrm{LN}$ assets } & $-0.10^{* * *}$ & & & & $-0.02^{*}$ & & & $-0.05^{* * *}$ \\
\hline & $(0.00)$ & & & & $(0.10)$ & & & $(0.01)$ \\
\hline \multirow{2}{*}{$\begin{array}{c}\text { M\&A assets } \\
\text { (thousand USD) }\end{array}$} & 0.00 & & & & & $0.00004^{* * *}$ & & 0.00 \\
\hline & $(0.13)$ & & & & & $(0.01)$ & & $(0.18)$ \\
\hline \multirow{2}{*}{ Rel. share } & $0.39 * *$ & & & & & & $-0.14^{* * *}$ & \\
\hline & $(0.02)$ & & & & & & $(0.00)$ & \\
\hline \multirow{2}{*}{ _cons } & $0.88^{* * *}$ & 0.01 & $0.19^{* * *}$ & $0.22^{* * *}$ & $0.44^{* *}$ & $0.11^{* * *}$ & $0.26^{* * *}$ & $0.44 * * *$ \\
\hline & $(0.00)$ & $(0.74)$ & $(0.00)$ & $(0.00)$ & $(0.01)$ & $(0.00)$ & $(0.00)$ & $(0.00)$ \\
\hline Observations (n) & 411 & 411 & 411 & 411 & 411 & 411 & 411 & 411 \\
\hline
\end{tabular}

Notes: the variables are described in Table 2. Estimation of the standard error with bootstrapping. Estimation between quantiles 0.25 and 0.75 .

$M \& A=$ mergers and acquisitions.

$* * *, * *, *=$ significance at 1,5 , and $10 \%$, respectively.

Source: Elaborated by the authors.

These results are consistent with the findings of Song and Walkling (2000), that is, in heated markets, the abnormal returns of M\&A events, for the rivals to the acquiring banks, tend to be positive. The M\&A value indicator presents a positive coefficient, which shows that the more heated the market is by high M\&A values, the greater the abnormal return of the rival banks is.

\subsubsection{Effective date of bank M\&A events}

The third step of the investigation aims to analyze the reaction of the investors of the rival banks to actual bank M\&A events, observing the effective date of this event, that is, this analysis addresses the date of the occurrence of the event.

The constant means model (model 1) was the one chosen to analyze the mean cumulative abnormal returns, the same one adopted by Hankir et al. (2011). That article is one of the few to address the question of analyzing the effective date of M\&As, since the studies generally use the date of the announcement as the only analysis date. This occurs since the database of Hankir et al. (2011), as well as that of this paper, enables the separation of this analysis. In addition, in this analysis, model 1 is the only one to present results that are robust for heteroskedasticity and possible non-normalities of the CARs distributions. In this model there is a correction of the variabilities of the CARs, both for heteroskedasticity via the Patell (1976) and Boehmer et al. (1991) tests and non-normality of the CAR distributions by the Cowan (1992) and Corrado (2011) tests; only in the $-15,+15$ window do the Boehmer et al. (1991) and Cowan (1992) tests have no significance. In this context, the average cumulative abnormal returns for the rivals of the acquiring banks presented positive values, which shows that when the merger of rival banks is implemented on its effective date, investors wait for the market to be heated and for the probability of the banks in which they have shares merging to increase, as highlighted by Song and Walkling (2000). This type of mechanism makes the value of the rival banks of recentlymerged ones increase.

Table 9 presents the average CARs on the effective date of the bank M\&As of the rivals of the acquiring banks. 
Table 9

Date of the announcement of bank mergers and acquisitions (M\&A) in actually implemented events

\begin{tabular}{|c|c|c|c|c|c|}
\hline & Model 1 & Model 2 & Model 3 & Model 4 & Model 5 \\
\hline CAR $(-20,+20)$ & 0.0623 & -0.0234 & 0.0125 & 0.0059 & -0.0051 \\
\hline time-series t-test & $0 * * *$ & $0.0041^{* * *}$ & 0.1784 & 0.5313 & 0.581 \\
\hline cross-sectional t-test & $0 * * *$ & $0.0001^{* * *}$ & $0.0802^{*}$ & 0.4022 & 0.3731 \\
\hline Patell z & $0 * * *$ & NA & 0.4977 & 0.8528 & 0.2418 \\
\hline Boehmer et al. & $0.0363^{* *}$ & 0.2703 & 0.781 & 0.9528 & 0.5284 \\
\hline Corrado rank & $0.0068^{* * *}$ & 0.3247 & 0.7678 & 0.5798 & 0.8046 \\
\hline sign test & $0.0287^{* *}$ & $0 * * *$ & 0.8692 & 0.7107 & 0.1823 \\
\hline Pos $\mid$ Neg & $375 \mid 187$ & $289 \mid 273$ & $231 \mid 227$ & $229 \mid 229$ & $206 \mid 252$ \\
\hline CAR $(-15,+15)$ & 0.0352 & -0.0309 & -0.0039 & -0.0093 & -0.0172 \\
\hline time-series t-test & $0 * * *$ & $0 * * *$ & 0.6263 & 0.2547 & $0.0328 * *$ \\
\hline cross-sectional t-test & $0 * * *$ & $0 * * *$ & 0.5198 & 0.1303 & $0.001^{* * *}$ \\
\hline Patell z & $0.0054 * * *$ & $\mathrm{NA}$ & 0.2083 & $0.0946^{*}$ & $0.0042^{* * *}$ \\
\hline Boehmer et al. & 0.2325 & $0.0857^{*}$ & 0.5572 & 0.4373 & 0.1539 \\
\hline Corrado rank & $0.0816^{*}$ & 0.1438 & 0.3077 & 0.2236 & 0.3255 \\
\hline sign test & 0.655 & $0 * * *$ & 0.1983 & 0.1618 & $0 * * *$ \\
\hline Pos|Neg & $355 \mid 207$ & $270 \mid 292$ & $219 \mid 239$ & $218 \mid 240$ & $175 \mid 283$ \\
\hline CAR $(-10,+10)$ & 0.0437 & -0.0286 & -0.0012 & -0.0057 & -0.0102 \\
\hline time-series t-test & $0 * * *$ & $0 * * *$ & 0.8564 & 0.396 & 0.1244 \\
\hline cross-sectional t-test & $0 * * *$ & $0 * * *$ & 0.8325 & 0.31 & $0.0473^{* *}$ \\
\hline Patell z & $0 * * *$ & NA & 0.1257 & $0.0427^{* *}$ & $0.0045^{* * *}$ \\
\hline Boehmer et al. & $0.0365^{* *}$ & $0.0285^{* *}$ & 0.5301 & 0.4065 & 0.2294 \\
\hline Corrado rank & $0.0066^{* * *}$ & $0.0331^{* *}$ & 0.1563 & 0.1061 & 0.1669 \\
\hline sign test & $0.0012^{* * *}$ & $0^{* * *}$ & $0.0001^{* * *}$ & $0.0001^{* * *}$ & $0 * * *$ \\
\hline Pos $\mid$ Neg & $387 \mid 175$ & $258 \mid 302$ & $192 \mid 266$ & $190 \mid 268$ & $176 \mid 282$ \\
\hline
\end{tabular}

Note: in this table, the cumulative abnormal return (CAR) refers to the mean of the CARs of each bank in the period analyzed.

$N A=$ non-argument.

$* * *, * *, *$ significance at 1,5 , and $10 \%$, respectively.

Source: Elaborated by the authors.

Figure 1 presents the average CARs for the period of the window of events $(-20,+20)$. The positive result for the chosen model can be observed in the three windows tested.

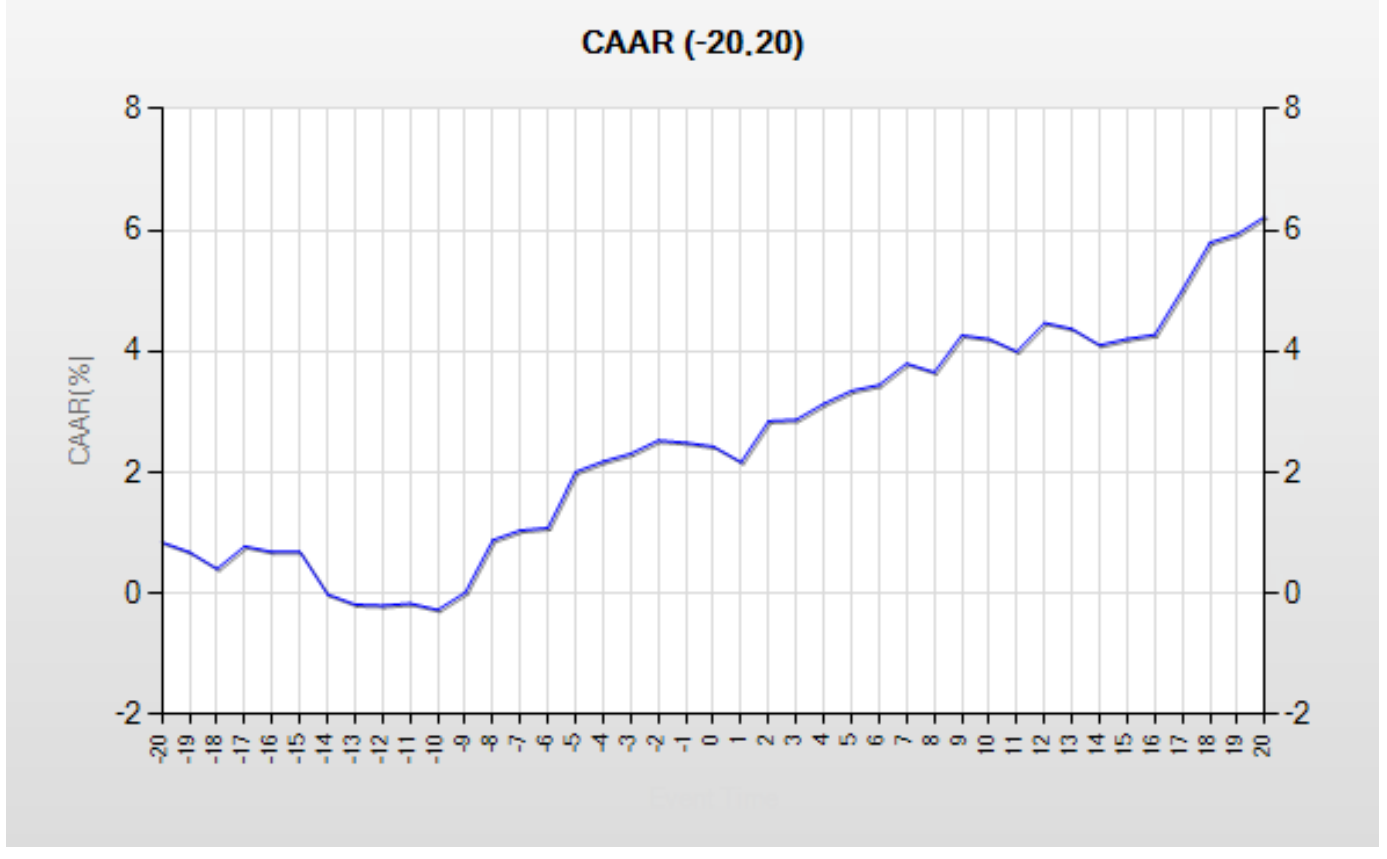

Figure 1 Cumulative abnormal return (CAR) of the constant means model

Source: Elaborated by the authors. 
It is observed that, in practically the whole period, the abnormal returns were positive. This shows that the rival banks rose in value with the merger of the acquiring banks, possibly due to the M\&A market being heated.

\subsubsection{Date of the announcement of bank M\&A events (pending)}

The fourth step of the investigation is to analyze the effect that the announcement of bank M\&A events that did not occur have over the pricing of the rival banks. In this field of analysis, it is observed that the investors of the rivals of the acquiring banks negatively priced the shares of their banks, possibly due to the non-occurrence of the events, destroying value of the firms that were not merged (Varmaz \& Laibner, 2016). The model used was the constant means one (model 1). Despite this model not using the ratio of the market with financial assets, only its mean over time, this same model was used by Hankir et al. (2011). That article is one of the few to address the question of pending M\&As; in general, the other studies cited use concrete or total M\&As. Due to this reason, the choice of model 1 followed the approach of Hankir et al. (2011), in addition to this model presenting more significant hypothesis tests, correcting possible problems of heteroskedasticity and non-normality of the CARs. It is observed from Table 4 that the economicfinancial indicators of the banks analyzed present high variability; this variability causes heteroskedasticity problems and these problems generate longer CAR distribution tails. The negative average CAR found in Table 10 shows that the investors of the rival banks are able to observe when the rumor is not integralized in the business and this reduces the possibility of M\&As in the rival banks of the acquirer ones. According to Hankir et al. (2011), the probability of acquisition hypothesis implies that shareholders do not expect their firms to be merged when announced events are canceled; with this, investors observe that their banks have tended to have a lower probability of M\&A. Table 10 presents the results mentioned here.

Table 10

Date of the announcement of bank mergers and acquisitions $(M \& A)$ in pending events

\begin{tabular}{|c|c|c|c|c|c|}
\hline & Model 1 & Model 2 & Model 3 & Model 4 & Model 5 \\
\hline CAR $(-20,+20)$ & -0.0351 & 0.014 & 0.0087 & 0.0136 & -0.0101 \\
\hline time-series t-test & $0.0003^{* * *}$ & 0.1384 & 0.3452 & 0.1503 & 0.2744 \\
\hline cross-sectional t-test & $0^{* * *}$ & $0.0334^{*}$ & 0.1871 & $0.0401^{* *}$ & 0.1112 \\
\hline Patell z & $0.0002^{* * *}$ & NA & 0.2224 & $0.0817^{*}$ & 0.6402 \\
\hline Boehmer et al. & 0.1383 & 0.3475 & 0.5997 & 0.4542 & 0.8344 \\
\hline Corrado rank & $0.0654^{*}$ & 0.1034 & 0.1477 & 0.1282 & 0.1766 \\
\hline sign test & $0 * * *$ & 0.1083 & 0.2207 & $0.0673^{*}$ & 0.9981 \\
\hline Pos $\mid$ Neg & $114 \mid 176$ & $169 \mid 121$ & $152 \mid 128$ & $157 \mid 123$ & $132 \mid 148$ \\
\hline CAR $(-15,+15)$ & -0.0514 & 0.0196 & 0.0056 & 0.0105 & -0.0085 \\
\hline time-series t-test & $0^{* * *}$ & $0.0167^{* *}$ & 0.4812 & 0.2011 & 0.2861 \\
\hline cross-sectional t-test & $0 * * *$ & $0.0016^{* * *}$ & 0.364 & $0.0906^{*}$ & 0.1535 \\
\hline Patell z & $0 * * *$ & NA & 0.369 & 0.1361 & 0.5681 \\
\hline Boehmer et al. & $0.0156^{* *}$ & 0.2089 & 0.7185 & 0.5499 & 0.8148 \\
\hline Corrado rank & $0.0023^{* * *}$ & $0.0251 * *$ & $0.0749 *$ & $0.0572 *$ & $0.0957^{*}$ \\
\hline sign test & $0 * * *$ & $0.0501 *$ & 0.8816 & 0.1764 & 0.9066 \\
\hline Pos|Neg & $93 \mid 197$ & $172 \mid 118$ & $143 \mid 137$ & $153 \mid 127$ & $133 \mid 147$ \\
\hline CAR $(-10,+10)$ & -0.0442 & 0.0143 & 0.0017 & 0.0054 & -0.0079 \\
\hline time-series t-test & $0 * * *$ & $0.0342 *$ & 0.7974 & 0.4262 & 0.2298 \\
\hline cross-sectional t-test & $0^{* * *}$ & $0.0055^{* * *}$ & 0.7413 & 0.2995 & 0.1132 \\
\hline Patell z & $0^{* * *}$ & NA & 0.5734 & 0.274 & 0.5189 \\
\hline Boehmer et al. & $0.0146^{* *}$ & 0.2652 & 0.8289 & 0.6742 & 0.8012 \\
\hline Corrado rank & $0.0022^{* * *}$ & $0.0258^{*}$ & $0.0823^{*}$ & $0.0647^{*}$ & $0.0975^{*}$ \\
\hline sign test & $0^{* * *}$ & $0.0017^{* * *}$ & 0.2691 & 0.2658 & 0.1202 \\
\hline Pos $\mid$ Neg & $94 \mid 196$ & $182 \mid 108$ & $151 \mid 129$ & $151 \mid 129$ & $145 \mid 135$ \\
\hline
\end{tabular}

Note: in this table, the cumulative abnormal return (CAR) refers to the mean of the CARs of each bank in the period analyzed.

$N A=$ non-argument .

***,,$* * *$ significance at 1,5 , and $10 \%$, respectively.

Source: Elaborated by the authors. 
It is worth highlighting that, in the robustness models (models 2, 3, and 4), the results were positive, which may produce different analyses. In any event, it is observed via the Patell (1976) test that there is no correction of heteroskedasticity in the models mentioned. In the model chosen there is a correction of the variabilities of the CARs, both for heteroskedasticity via the Patell (1976) and Boehmer et al. (1991) tests and for non-normality of the CAR distributions by the Cowan (1992) and Corrado (2011) tests in all the windows tested.

\section{CONCLUDING REMARKS}

In general, studies that contemplate a process analysis of M\&A waves are limited to observing the signs of the abnormal returns of rivals of recently-merged firms to determine asymmetric effects in this M\&A waves market. Yet, the reason for the abnormal returns of the rivals of recently-merged firms arising from the M\&A processes is not widely addressed in the literature. Just like the article by Song and Walkling (2000), this one shows, using cross-sectional analyses, that the acquisition probability via heated markets hypothesis is evident.

In this study, 43 mergers between Brazilian banks and 26 bank assets covering the period from 2005 to 2015 are identified. The results indicate the acquisition probability hypothesis. It is observed that the possible cause of positive cumulative abnormal returns of the rivals of recentlymerged acquiring banks are the slightly positive profitability indicators of the merged banks (ROA and ROE), and the market concentration and bank size indicators showed negative results in relation to the cumulative abnormal returns of the rival banks of the recently-merged ones. This result indicates that, in more concentrated markets, the probability of rival banks merging decreases. The results found in the case of pending mergers present negative CAR values for the rival banks, showing that in situations where mergers do not occur, rival banks have negative cumulative abnormal returns values. Two points are worth highlighting: the first of them refers to the fact that the robustness analysis models presented divergent results in some of the tests carried out. Yet, the overall results of the models chosen were consistent with the empirical support literature. The second is that the effects of the bank M\&As were not statistically significant in the analysis of the rivals of the acquiring banks.

The results indicate that the Brazilian bank M\&As, in the period analyzed, can be observed via the M\&A waves mechanism, which can be demonstrated in a heated market. This study is consistent with the literature, indicating the possible reason for bank M\&As: a market tendency mechanism. It is shown that bank M\&As are generated by heated markets. This mechanism tends to generate short term inefficiency, since the impact of the M\&As are not evaluated, but rather the concern of managers that their banks will lose market. It is observed that the empirical results of this paper suggest that investors and market analysts should assess bank M\&As with more caution, since these can occur due to market tendencies and not value gains.

One limitation that is apparent in this study is it does not contemplate the conditional variance in the measurement of the cumulative abnormal returns of rival banks. In future studies, we suggest methods that cover volatility and conditional variance, such as those of the generalized autoregressive conditional heteroskedasticity (GARCH) family.

\section{REFERENCES}

Andriosopoulos, D., \& Yang, S. (2015). The impact of institutional investors on mergers and acquisitions in the United Kingdom. Journal of Banking \& Finance, 50, 547-561.

Araújo, C. A. G. de, Goldner, F., Brandão, M. M., \& Oliveira, F. R. (2007). Estratégia de fusão e aquisição bancária no brasil: evidências empíricas sobre retornos. Revista Contemporânea de Economia E Gestão, 5(2), 7-20.

Arık, E., \& Kutan, A. M. (2015). Do mergers and acquisitions create wealth effects? Evidence from twenty emerging markets. Eastern European Economics, 53, 529-550.

Asimakopoulos, I., \& Athanasoglou, P. P. (2013). Revisiting the merger and acquisition performance of European banks. International Review of Financial Analysis, 29, 237-249.
Asquith, P. (1983). Merger bids, uncertainty, stockholder returns. Journal of Financial Economics, 11, 51-83.

Behr, A. (2010). Quantile regression for robust bank efficiency score estimation. European Journal of Operational Research, 200(2), 568-581.

Beltratti, A., \& Paladino, G. (2013). Is M\&A different during a crisis? Evidence from the European banking sector. Journal of Banking \& Finance, 37(Special Issue), 5394-5405.

Boehmer, E., Musumeci, J., \& Poulsen, A. B. (1991). Event-study methodology under conditions of event-induced variance. Journal of Financial Economics, 30, 253-272. 
Brito, G., Batistella, F., \& Famá, R. (2005). Fusões e aquisições no setor bancário: avaliação empírica do efeito sobre o valor das ações. Revista de Administração da Universidade de São Paulo, 49(4), 353-360.

Brown, S. J., \& Warner, J. B. (1980). Measuring security price performance. Journal of Financial Economics, 8(3), 205-258.

Brown, S. J., \& Warner, J. B. (1985). Using daily stock returns: The case of event studies. Journal of Financial Economics, 14(1), 3-31.

Campa, M., \& Hernando, I. (2006). M \& As performance in the European financial industry. Journal of Banking \& Finance, 30, 3367-3392.

Chiang, T. C., \& Zheng, D. (2010). An empirical analysis of herd behavior in global stock markets. Journal of Banking and Finance, 34(8), 1911-1921.

Corrado, C. (2011). Event studies: A methodology review. Accounting \& Finance, 51(1), 207-234.

Cowan, A. R. (1992). Nonparametric event study tests. Review of Quantitative Finance and Accounting, 2(4), 343-358.

Cummins, J. D., Lewis, C. M., \& Wei, R. (2006). The market value impact of operational loss events for US banks and insurers. Journal of Banking \& Finance, 30(10), 2605-2634.

Delong, G., \& DeYoung, R. (2007). Learning by observing: Information spillovers in the execution and valuation of commercial bank M\&As. The Journal of Finance, 62(1), 181216.

Dickey, D., \& Fuller, W. A. (1979). Distribution of the estimates for autoregressive time series with a unit root. Journal of the American Statistical Association, 74(366), 427-431.

Dodd, P. (1980). Merger proposals, management discretion and stockholder wealth. Journal of Financial Economics, 8(2), 105-137.

Dodd, P., \& Ruback, R. (1977). Tender offers and stockholders returns: An empirical analysis. Journal of Financial Economics, 5(3), 351-373.

Duso, T., Gugler, K., \& Yurtoglu, B. (2010). Is the event study methodology useful for merger analysis? A comparison of stock market and accounting data. International Review of Law and Economics, 30(2), 186-192.

Eckbo, B. (1983). Horizontal mergers, collusion, and stockholder wealth. Journal of Financial Economics, 11(1-4), 241-273.

Eckbo, B. (1985). Mergers and the market concentration doctrine : Evidence from the capital market. Journal of Business, 58(3), 325-349.

Eckbo, B., \& Wier, P. (1985). Antimerger policy under the HartScott-Rodino Act: A reexamination of the market power hypothesis. The Journal of Law and Economics, 28(1), 119-149.

Elliott, G., Rothenberg, T. J., \& Stock, J. H. (1996). Efficient tests for an autoregressive unit root. Econometrica, 64(4), 813-836.

Hagendorff, J., Collins, M., \& Keasey, K. (2008). Investor protection and the value effects of bank merger announcements in Europe and the US. Journal of Banking and Finance, 32(7), 1333-1348.

Hankir, Y., Rauch, C., \& Umber, M. P. (2011). Bank M\&A: A market power story? Journal of Banking and Finance, 35(9), 2341-2354.
Hax, A. C., \& Majluf, N. S. (1983). The use of the growth-share matrix in strategic planning. Interfaces, 13(1), 46-60.

Houston, J. F., \& Ryngaert, M. D. (1994). The overall gains from large bank mergers. Journal of Banking \& Finance, 18(6), 1155-1176.

Koenker, R., \& Bassett, G. (1978). Regression quantiles. Econometrica, 46(1), 33-50.

Kolari, J. W., \& Pynnönen, S. (2010). Event study testing with cross-sectional correlation of abnormal returns. Review of Financial Studies, 23(11), 3996-4025.

Kothari, S. P., \& Warner, J. B. (2007). Econometrics of event studies. In Handbook of empirical corporate finance SET (pp. 3-36). Amsterdam: Elsevier.

Koutsomanoli-Filippaki, A., Mamatzakis, E., \& Pasiouras, F. (2013). A quantile regression approach to bank efficiency measurement. In Efficiency and productivity growth: Modelling in the financial services industry (pp. 253-266). Chichester: John Wiley \& Sons.

Lintner, J. (1965). The valuation of risk assets and the selection of risky investments in stock portfolios and capital budgets. The Review of Economics and Statistics, 47(1), 13-37.

Lown, C. S., Osler, C. L., Strahan, P. E., \& Sufi, A. (2000). The changing landscape of the financial services industry: What lies ahead? FRBNY Economic Policy Review, (October), 39-55.

MacKinlay, A. (1997). Event studies in economics and finance. Journal of Economic Literature, 35(1), 13-39.

Patell, J. M. (1976). Corporate forecasts of earnings per share and stock price behaviour: Empirical tests. Journal of Accounting Research, 14(2), 246-276.

Pessanha, G. R. G., Calegario, C. L. L., Sáfadi, T., \& Ázara, L. N. de. (2012). Impactos das estratégias de fusão e aquisição na rentabilidade dos bancos adquirentes: uma aplicação dos modelos de intervenção no setor bancário brasileiro. Revista de Administração Mackenzie, 13(5), 101-134.

Phillips, P., \& Perron, P. (1988). Testing for a unit root in time series regression. Biometrika, 75(2), 335-346.

Scholes, M., \& Williams, J. (1977). Estimating betas from nonsyncronous data. Journal of Financial Economics, 5(3), 309-327.

Sharpe, W. (1964). Capital asset prices: A theory of market equilibrium under conditions of risk. The Journal of Finance, 19(3), 425-442.

Sherman, H. D., \& Rupert, T. J. (2006). Do bank mergers have hidden or foregone value? Realized and unrealized operating synergies in one bank merger. European Journal of Operational Research, 168(1), 253-268.

Song, M. H., \& Walkling, R. A. (2000). Abnormal returns to rivals of acquisition targets: A test of the "acquisition probability hypothesis." Journal of Financial Economics, 55(2), 143-171.

Tabak, B. M., Fazio, D. M., \& Cajueiro, D. O. (2013). Systemically important banks and financial stability: The case of Latin America. Journal of Banking and Finance, 37(10), 3855-3866.

Varmaz, A., \& Laibner, J. (2016). Announced versus canceled bank mergers and acquisitions: Evidence from the European banking industry. Journal of Risk Finance, 17(5), 510-544. 